\title{
KROMOSZÓMÁK ÉS GÉNEK - KOLLER PIUS KÁROLY ÚTJA PANNONHALMÁTÓL A FULHAM ROADIG ${ }^{1}$
}

\section{CHROMOSOMES AND GENES - THE JOURNEY OF PEO CHARLES KOLLER FROM PANNONHALMA TO FULHAM ROAD}

\author{
Varga Máté \\ PhD, habil, egyetemi docens, Eötvös Loránd Tudományegyetem Genetikai Tanszék Biológiai Intézet, Budapest \\ mvarga@ttk.elte.hu
}

\section{ÖSSZEFOGLALÁS}

A 20. század történelmi viharai számos szokatlan karrier születéséhez vezettek a magyar biológián belül is. Nem sok kétség fér hozzá, hogy ezek egyike Koller Pius Károly életútja, aki pannonhalmi bencés szerzetes tanárból vált a brit és nemzetközi genetika egyik elismert figurájává, a sugárzás okozta mutációk fontos szakértőjévé. Hosszú és sikeres karrierje során a modern genetika sok képviselőjével alakított ki fontos kapcsolatokat, és kutatási témáinak változása egyben azt is jól tükrözi, hogy néhány évtized alatt milyen óriásit fejlődött az örökítő anyag szerepéről és változásáról rendelkezésünkre álló ismeretanyag. Életútja abban is szokatlan, hogy sok más kutatóval ellentétben, akik engedték magukat elcsábítani az eugenika áltudománya által, Koller épp az ellenkező utat járta be, és a genetika mélyebb megismerése eltávolította a "fajtudományok" bűvköréből, amelybe fiatalkori mentora, Méhelÿ Lajos miatt került.

\section{ABSTRACT}

The tumultuous years of the $20^{\text {th }}$ century often resulted in unusual carrier paths for Hungarian biologists. Undoubtedly, the life of Peo Charles Koller was amongst the more unusual ones. Starting as a Benedictine monk-teacher Koller became an influential figure of international and British genetics, a well-known expert of genetic alterations resulting from ionizing radiation. During his long and successful career Koller forged important personal contacts with the leading figures of modern genetics and his choice of research topics reflects how much the science of genetics has changed in a few decades. His career is also unusual because, unlike many of his contemporaries who were seduced by the pseudo-science of eugenics, his journey led in the opposite direction, and a deeper knowledge of genetics made him to completely reject the views of his doctoral advisor, the well-known anti-Semite, Lajos Méhelÿ.

${ }^{1}$ Rendhagyó biológussorsok a 20. században. Az MTA Tudomány- és Technikatörténeti Bizottság előadóülésén, Budapesten, 2019. szeptember 13-án elhangzott előadás szerkesztett változata. 
Kulcsszavak: genetika, rákkutatás, eugenika, Magyar Biológiai Kutatóintézet, Drosophila, nemi kromoszómák

Keywords: genetics, cancer research, eugenics, Hungarian Biological Research Institute, Drosophila, sex chromosomes

PROLÓGUS

A Magyar Televízió 1980. június 6-án tűzte műsorra azt a portréfilmet, amely az ekkor már néhány hónapja halott, de életében jelentős nemzetközi elismertségnek örvendő Koller Pius Károly (angol nyelvterületen Peo Charles Kollerként ismert) rákkutatóról készült. A film bő egy évvel korábban felvett zárójelenetében a Duna-korzón felesége társaságában ülő idős tudós szociobiológiai fejtegetését hallhatjuk:

„Az emberekben van egy bizonyos fokú önzés, de ezt határok között kell tartani, mert ha túl messzire megy, veszekedésre, verekedésre és háborúra vezet. És ez egy olyan nagy probléma, hogy az emberiség jövője függhet attól, hogy meg tudjuk állapítani, mi az oka, és hogyan lehetne ezen változtatni. Persze ez nemcsak biológiai, hanem szociális és politikai kérdés is. Rengeteg igazságtalanság van az életben, meg a nemzetek között is. Ezeket a nehézségeket valahogyan tisztázni kell és megoldani. A szociális problémák nagyok, egyes népeknél a gazdagok és szegények közti különbségek óriásiak. Ezek olyan faktorok, amelyek mind hozzájárulnak, hogy az emberek önzését és az agresszív tendenciáit kihozzák, és így a politikának bele kell ebbe avatkozni."

Sajnos a portréfilmből már nem derül ki, hogy ezek a mai füllel is elgondolkodtató, negyven évvel ezelőtt pedig kifejezetten progresszívnak számító gondolatok egy figyelemre méltó karakterfejlődés eredményét tükrözik, amely során a biológia iránt naivan rajongó és az eugenikával kacérkodó pannonhalmi szerzetesnövendékből korának egyik befolyásos és nagyon produktív genetikusa és rákkutatója vált.

\section{A PANNONHALMI ÉVEK}

Koller Károly 1901. március 4-én született Nagykanizsán, egy hétgyerekes család hatodik gyerekeként. Mint élete végén írt memoárjaiból kiderül, gyerekkori élményei egyáltalán nem füződnek Nagykanizsához, ugyanis mozdonyvezető, később vasúti adminisztrátor édesapja munkája miatt a család rövid időn belül Szombathelyre költözött. Koller itt töltötte gyerekkorát, és tanulmányait a helyi katolikus iskolákban kezdte el. 
A mélyen vallásos római katolikus szülők a korszellemnek megfelelő karriert szántak két fiuk számára: az idősebb Istvánt katonai pályára küldték, míg Károlyból tanárt szerettek volna faragni. Az első világháború kitörése következtében fokozódó bizonytalanság miatt utóbbi a közeli Pannonhalmi Apátság intézményében tűnt a legkönnyebben biztosíthatónak, így Károly tizenöt évesen Pannonhalmára került. Hivatalosan 1916. augusztus 6-án lépett be a rendbe, és ekkor kapta a Pius nevet is (1. kép).

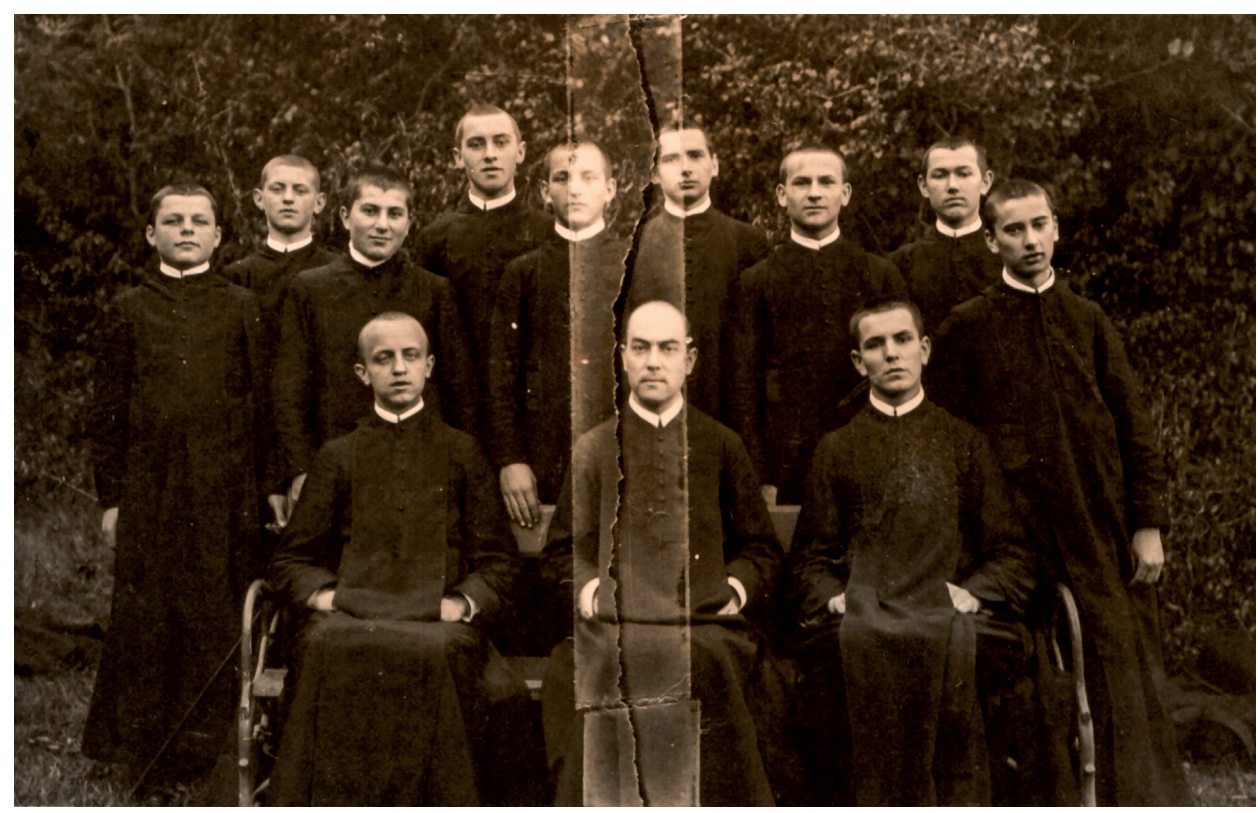

1. kép. A Pannonhalmi Apátság novíciusai 1917-ben. A fiatal Pius a kép jobb szélén látható (Karin Koller)

Itt, az apátság kötelékében érte meg az I. világháború végét és az ezzel járó turbulenciát is. Maga is elkapta a tomboló spanyolnáthát, majd 1919-ben, a Tanácsköztársaság ideje alatt Grazban, Bécsben, illetve Kassán töltött időt, az ottani bencés intézményekben. De amint a körülmények lehetővé tették, visszatért Pannonhalmára, és folytatta tanulmányait az apátság falai közt.

Természettudományos érdeklődése hamar nyilvánvalóvá vált tanárai és az apátság vezetôi számára, és hamarosan megszületett az elhatározás: Pius egyetemen folytathatja tanulmányait, hogy később a rend valamelyik középiskolájában oktathasson természetismeretet. Így aztán 1921-től Koller a budapesti Pázmány Péter (ma Eötvös Loránd) Tudományegyetem zoológia és botanika szakának hallgatója lett. 
Az egyetem első két évében ez az affiliáció inkább csak formalitás volt: Koller ideje nagyobb részét továbbra is Pannonhalmán töltötte, itt készülhetett fel a vizsgáira, és csak harmadévtől kellett Budapestre költöznie. Eddigre pannonhalmi tanárai, Kál Adorján és Kálovics Rezső atyák már kellően felkeltették az ifjú szerzetes érdeklődését az öröklődés iránt. Tölük hallott először Charles Darwinról és Gregor Mendelről, nekik köszönhetően találkozhatott Ábrahám Ambrussal, a kor neves pap zoológusával, valamint Gelei Józseffel, a magyar és nemzetközi sejtbiológia egyik úttörőjével. Utóbbi gerinctelenek szaporodásáról szóló, kromoszómafestésekkel színezett citológiai előadása különösen nagy hatással volt rá, mintegy megelőlegezve, hogy alig egy évtizeddel később Koller maga is az akkor még ifjú citogenetika tudománynak egyik úttörőjévé válik majd.

Visszaemlékezései alapján a budapesti évek (beleértve az egyetemi diploma utáni doktori tanulmányokat is) némileg csalódást okoztak, amiben fontos szerepe lehetett a zoológiát oktató Méhelÿ Lajosnak. Koller élete végén írt visszaemlékezésében ellentmondást nem türő autokrataként írja le a maga korának kiemelkedő zoológusaként és egyben megveszekedett antiszemitaként számontartott Méhelÿt (Gyurgyák, 2012). Ugyanakkor, mint ahogy még visszatérünk rá, kettejük kapcsolata valószínüleg komplexebb volt, hiszen Koller doktori tanulmányait is Méhelÿ vezetése alatt végezte el később.

\section{KINYÍLIK A VILÁG}

Az ifjú bencés tanár életének egyik sorsfordító eseménye lett az 1927. szeptember 4. és 10. közt megtartott X. Nemzetközi Zoológiai Kongresszus. A kongreszszus eredetileg 1916-ban lett volna esedékes, de a világháború és az azt követő bizonytalan időszak nem tette lehetővé, hogy korábban megtartsák. A korabeli magyar kultúrdiplomácia kiemelten kezelte a nagy érdeklődés mellett megtartott eseményt, ahol kilenc szakosztály harminckét ülésén 246 előadás hangzott el.

Az ifjú Koller számára a kongresszus két meghatározó élményt is hozott: egyrészt ismeretséget kötött a vele egyidős Curt Sternnel, akinek előadásából először hallhatta az akkor virágzásnak induló Drosophila-genetika alaptéziseit, másrészt a Sejtkutató szakosztály Korányi Klinikán tartott ülésén megismerkedett a szövettenyésztés kísérleti paradigmájával.

Utóbbi annyira elbüvölte, hogy amint kiderült, hogy a Korányiban a Csaba Margit, Németh László és Sellei Camillo alkotta fiatal kutatócsoport ilyen irányú kísérleteket végez, bekönyörögte magát, és a következő pár hónap során maga is részesévé vált a vitális festések emlörákra gyakorolt hatását vizsgáló munkának (Koller, 1963). Valószínűleg ennek a munkának köszönhetően kerülhetett be 1928 nyarán az épp csak müködni kezdő tihanyi Magyar Biológiai Kutatóintézetbe vendégkutatóként. 
A gróf Klebelsberg Kunó vallás- és közoktatásügyi miniszter személyes bábáskodása mellett, a nápolyi Zoológiai Állomás mintájára létrejövő új kutatóintézet a háború utáni Magyarország egyik kulcsfontosságú kutatási központja lett, ahol az állandó személyzet segítségével hosszabb-rövidebb ösztöndíjak keretében belés külföldi tanárok és tudósok folytathattak kutatómunkát. Koller kapcsolata az intézettel végül nem korlátozódott az „egynyári” kalandra, mert 1929-ben már az Entz Géza vezette intézet alkalmazottai közt fedezhetjük föl a nevét, és az adjunktusi pozíciójáról csak 1935-ben mondott le. Hogy pontosan miképp került Budapestről Tihanyba, és miképp vált ezáltal középiskolai tanárból végleg kutatóvá, nem tudjuk pontosan, bár az intézet tőszomszédságában levő Tihanyi Apátság közelsége valószínúleg segítette, hogy a bencés renden belüli felettesei áldásukat adják a váltásra (ellentétben más, bentlakásos intézeti alkalmazottakkal, a bencés tanár-kutató az Apátságban lakott).

Ugyanakkor az 1929-1935 közti időszakban a fiatal Koller csak pár futó hónapot töltött Tihanyban, a fennmaradó időszakban az Egyesült Királyság különböző kutatóintézeteiben folytatott ösztöndíjas munkát.

\section{A CAMBRIDGE-LONDON-EDINBURGH-TENGELY}

Az első angliai tanulmányútra szinte véletlenül került sor: eredetileg a berlini Kaiser Wilhelm Intézetbe utazott volna, de az utolsó pillanatban egy üresedés miatt megkaphatta a Cambridge-be, a kor legendás genetikusa, Reginald Punnett intézetébe szóló ösztöndíjat (Koller, 1971a). Az ekkor már hosszabb ideje az örökléstan bủvöletében élö fiatal kutatónak ez szinte hihetetlen szerencsének tünhetett, ugyanakkor a valóság kezdetben sokkal zordabbnak bizonyult. Nem pontosan tisztázott okok miatt ugyanis az ekkor még a Whittingehame Lodge falai közt működő Genetikai Tanszéken nem akadt számára hely, így a közeli Strangeways Laboratóriumba került. A kényszer szülte helyzet azonban szerencsésnek bizonyult, mert ugyanekkor egy másik magyar kutató, Szent-Györgyi Albert is ennek az intézetnek a falai között dolgozott, és munkássága nagy hatással volt Kollerre (Koller, 1971a). Ugyan közös cikkük nem született, de életre szóló barátságot kötöttek, és Szent-Györgyi tanította meg ifjú kollégájának azokat a biokémiai vizsgálatokat is, amelyek révén a szerencsétlenül induló ösztöndíj végül eredményesen zárult, és Koller maga is érdemben hozzá tudott járulni Punnett nyúlpigmentáció genetikájával kapcsolatos kutatásaihoz (Koller, 1930).

Talán a C-vitamin felfedezöjénél is fontosabb mentora lett Kollernek az ez idő tájt épp Cambridge-ben tartózkodó amerikai genetikus, Donald Lancefield, aki a Drosophila pseudoobscura világába vezette be a muslicagenetika iránt is érdeklődő ifjú magyar kutatót (Koller, 1971a). A kapcsolat annyira gyümölcsözőnek 
bizonyult, hogy amikor Lancefield pár hétre Edinburgh-be utazott, hogy az ottani kutatóintézet munkatársainak is bemutassa kutatásait, Koller vele tartott, és segített a Drosophila törzsek fenntartásában.

Az 1919-ben alapított edinburgh-i Animal Breeding Research Department az Egyesült Királyság első igazi genetikai tanszékének tekinthető. Első és sokáig egyetlen munkatársa Francis A. E. Crew volt, a brit genetika kiemelkedő alakja, aki karizmáját és kapcsolatait felhasználva 1930-ra az ország egyik legfontosabb genetikai kutatóközpontjává tette a helyet (ebből nőtt ki később a Dolly nevü klónozott birkát létrehozó Roslin Intézet is). Az 1931-től már Institute of Animal Genetics néven működő intézet sikerének a titka Crew nagyon sikeres személyzeti politikájában kereshető. Crew felismerte, hogy a kontinens számos államának szélsőségek felé sodródó politikája sok tehetséges kutatót késztetett országa elhagyására, akiknek befogadásával sikeres kutatócsoportot hozhat létre. Így kerültek Edinburgh-be a második világháború előtti években a szülőhazájukban származásuk miatt kirekesztett olasz származású Guido Pontecorvo és német Charlotte (Lotte) Auerbach, illetve pár évig a Szovjetunióban dolgozó és a sztálini megtorlás elől menekülő, későbbi Nobel-díjas, amerikai Herman J. Müller is.

Crew már első ott-tartózkodása során felfigyelt Kollerre, és segített elérni, hogy első ösztöndíja lejártával újabb ösztöndíjhoz juthasson. Ehhez persze arra is szükség volt, hogy az akkori pannonhalmi föapát, Kelemen Krizosztom, valamint a közoktatásért felelős államtitkár, Szily Kálmán egyaránt fantáziát látott az ifjú genetikus külföldi tapasztalatszerzésében. Így 1929 késő őszén egy újabb magyar állami ösztöndíjjal a zsebében Koller ismét egy évre Edinburgh-be utazott, Cambridge érintésével, majd 1931-ben, immár a Crew által biztosított anyagi fedezetnek köszönhetően visszatért. Gyakorlatilag ez az időszak tekinthető emigrációja kezdetének is, hiszen egy 1935-ben tett néhány napos hivatalos utat leszámítva csak évtizedekkel később lépett ismét hazai földre.

1931-es kiutazása elején az akkor még London mellett müködő John Innes Kutatóközpontban töltött egy rövidebb időszakot, a citogenetika alapjait lefektető Cyril Darlington vendégeként. Ezzel újabb élethosszig tartó barátság vette kezdetét, melyhez gyümölcsöző együttmüködések is kapcsolódtak. A kromoszómafestések révén Koller különböző emlösfajokban kezdte el tanulmányozni az ivarsejtek kialakulása során megfigyelhető rekombináció eseményét. Ennek a kutatásnak az eredménye a The Genetical and Mechanical Properties of Sex Chromosomes címü cikksorozat, amelynek nyolc cikkéből hétnek Koller vagy egyedüli, vagy társszerzője. És ehhez a munkához kapcsolódik annak a felismerése is, hogy morfológiai különbségeik ellenére az emlösök X és Y kromoszómái tartalmaznak homológ régiókat (Darlington et al., 1934).

A folyamatosan bővülő edinburgh-i csapat munkájára akkorra már világszerte felfigyeltek. Ez is oka lehet annak, hogy 1933-ban, a Nobel-díj-átadóra utazva 
Thomas Hunt Morgan is rövid idöre itt vendégeskedett, és megismerve Koller Drosophila pseudoobscurán végzett munkáját, meghívta Kaliforniába. Az 1936ban tett, több fontos kutatóközpontot is érintő kutatói látogatást egy Rockefeller-ösztöndíj tette lehetővé (melynek elnyerésében szerepe lehetett Szily Kálmán támogatásának is).

Amerikai tartózkodása lehetővé tette, hogy Koller megismerhesse a kor amerikai genetikusainak krémjét. Az egyik leggyümölcsözőbb kapcsolata a 20. század evolúcióbiológiájának kulcsfigurájával, a darwini és mendeli megközelítéseket ötvöző modern szintézis egyik atyjának tekintett, ukrán származású Theodosius Dobzhanskyval lett.

Dobzhansky szakmai főmüvének a The Genetics of Natural Populations (GNP) cikksorozat tekinthetö, amely során 1938 és 1975 között negyvenhárom cikkben lefektette a modern evolúcióbiológia alapjait. A cikksorozat kezdeti cikkei a természetes Drosophila pseudoobscura populációk genetikáját vizsgálták, és az első megfigyelések pont Koller látogatásának idején születtek. A kaliforniai Death Valleybe szervezett gyüjtőútjaira Koller is elkísérte Dobzhanskyt, és ennek az eredménye lett a szakma által később csak „GNP III”-ként emlegetett cikk (Koller, 1939), a GNP-sorozat két olyan cikkének egyike, amelyben maga Dobzhansky nem szerző(társ). A cikk lényege az a később Dobzhnasky által részletesebben is kidolgozott felismerés, hogy még természetes populációkban is jelen lehetnek káros recesszív allélok, ráadásul, a korabeli elméleteknek ellentmondóan, egymással érintkező populációkban eltérő arányban.

Edinburgh-be visszatérve Koller szinte egyböl a 7. Nemzetközi Genetikai Kongresszus szervezésébe vetette magát. A szakma utolsó nemzetközi összejövetelét az Egyesült Államokbeli Ithacában tartották 1932-ben, és a tervek szerint a következő kongresszust Moszkvában rendezték volna. Ennek eléréséhez a kor egyik legnagyobb genetikusa, Nyikolaj Vavilov az összes hazai és nemzetközi tekintélyét latba vetette, és végül mind a szakma, mind a Szovjet Tudományos Akadémia és a Központi Bizottság is támogatta a tervet. Később azonban a változó politikai széljárás és ezzel együtt a genetikát burzsoá tudománynak bélyegző liszenkoizmus térnyerése gyakorlatilag lehetetlenné tette, hogy az összejövetel szovjet földön kerüljön megrendezésre (pár éven belül Vavilovot bebörtönözték, és később fogságban lelte a halálát is). Crew remek diplomáciai érzékről téve tanúságot felajánlotta Edinburgh-öt mint helyszínt, amit a szervezők elfogadtak. Bár a szovjet delegáció végül nem utazhatott el a találkozóra, a résztvevők jelképesen Vavilovot választották a kongresszus elnökének.

A kalandos elő- és utótörténet mellett (az amerikai delegáció egy része a nácik által elsüllyesztett első brit hajón, az SS Athenián indult haza), a kongresszus legfontosabb eredménye az a kiáltvány lett, amelyet később a Nature is leközölt, és amelyben a korabeli genetika elitje (köztük Koller is) elítéli az ekkor már sok kutató, de főleg politikusok körében igen népszerủ eugenika főbb téziseit, hang- 
súlyozva, hogy a szociális körülmények és emberi attitüdök megváltoztatásával sokkal nagyobb eredményeket lehetne elérni, mint olyan tudománytalan megközelítésekkel, amelyek egész embercsoportokat próbálnak megbélyegezni „rossz” génekkel (Crew et al., 1939).

\section{ÚT A FULHAM ROADRA}

A kitörő második világháború az edinburgh-i genetikusok életét is felforgatta. Bár a bombázások itt nagyon ritkák voltak, a klasszikus kutatási témáikat a háború idejére félre kellett tenniük, és helyette olyan témákkal foglalkoztak, amelyek valamilyen módon a brit háborús szempontoknak is megfeleltek. Ez Crew csapata esetében a mustárgáz mutagén szerepének vizsgálata lett. A témaválasztás a korábbi kolléga, Herman J. Müller hatásának is köszönhető (évekkel korábban ő fedezte fel a röntgensugárzás mutagén szerepét), és később Lotte Auerbach számára ez hozta el a nemzetközi elismerést is (Beale, 1993).

Ennek a munkának tulajdonítható, hogy a spontán mutációk citogenetikájával ekkor már több éve foglalkozó Koller figyelme egyre inkább a mutagének indukálta kromoszóma-aberrációk felé fordult, és egyre többet foglalkozott a rák kialakulásával is. Ez az újdonsült érdeklődés motiválhatta abban is, hogy 1943ban megpályázzon egy kutatói pozíciót a londoni Fulham Roadon található Royal Cancer Hospitalben (későbbi Chester Beatty Laboratories), hogy a sugárzás hatásait tanulmányozza. Szakértelmét és elismertségét jelzi, hogy alig pár évvel később őt bízták meg, hogy elkészítse a brit kormánynak azt a titkos jelentést, amely az ionizáló sugárzások emberi szervezetre gyakorolt hatását taglalja (Koller, 1946).

1944-töl Koller már folyamatosan a Fulham Roadon dolgozott (2. kép), és közel két és fél évtizedes munkája során leukémiával, annak csontvelö-transzplantáción alapuló esetleges gyógyításával, valamint a transzplantáció során kialakuló vérvonal-kimérizmussal foglalkozott (Davies, 1980). A munka mellett fiatal kollégáinak egyik fontos mentora lett, és többek között a csecsemőmirigy szerepét feltáró Jacques Miller, illetve a T-sejtek felfedezésében fontos szerepet játszó Anthony Davies is az ő támogatása mellett kezdte el munkáját (Davies, 1980).

Végül 1969-ben vonult vissza az aktív kutatástól, azaz majdnem három évvel az akkori hivatalos nyugdíjkorhatár (65 év) elérése után - ennek oka, hogy az angol honosítási folyamat alatt valahol egy tévedés során az 1901. március 4-i születési dátumból 1904. április 3. lett, vagyis hivatalosan valóban csak ekkor jött el az ideje a nyugdíjba vonulásának.

A nyugdíj azonban nem unalmas semmittevést hozott számára, hiszen még 1969-ben a Nemzetközi Atomenergia Ügynökség (IAEA) felkérésére az indonéz Bangdunba utazott, hogy segítsen egy sugárzásos növénynemesítő program bein- 
dításában, majd 1970-től két éven keresztül a Harvardi Egyetem vendégkutatója volt. Ez volt az az időszak, amikor E. O. Wilson nagy hatású művének köszönhetően élénken érdeklődni kezdett a szociobiológia iránt, ahogy azt a halála előtti televíziós interjú is tanúsítja.

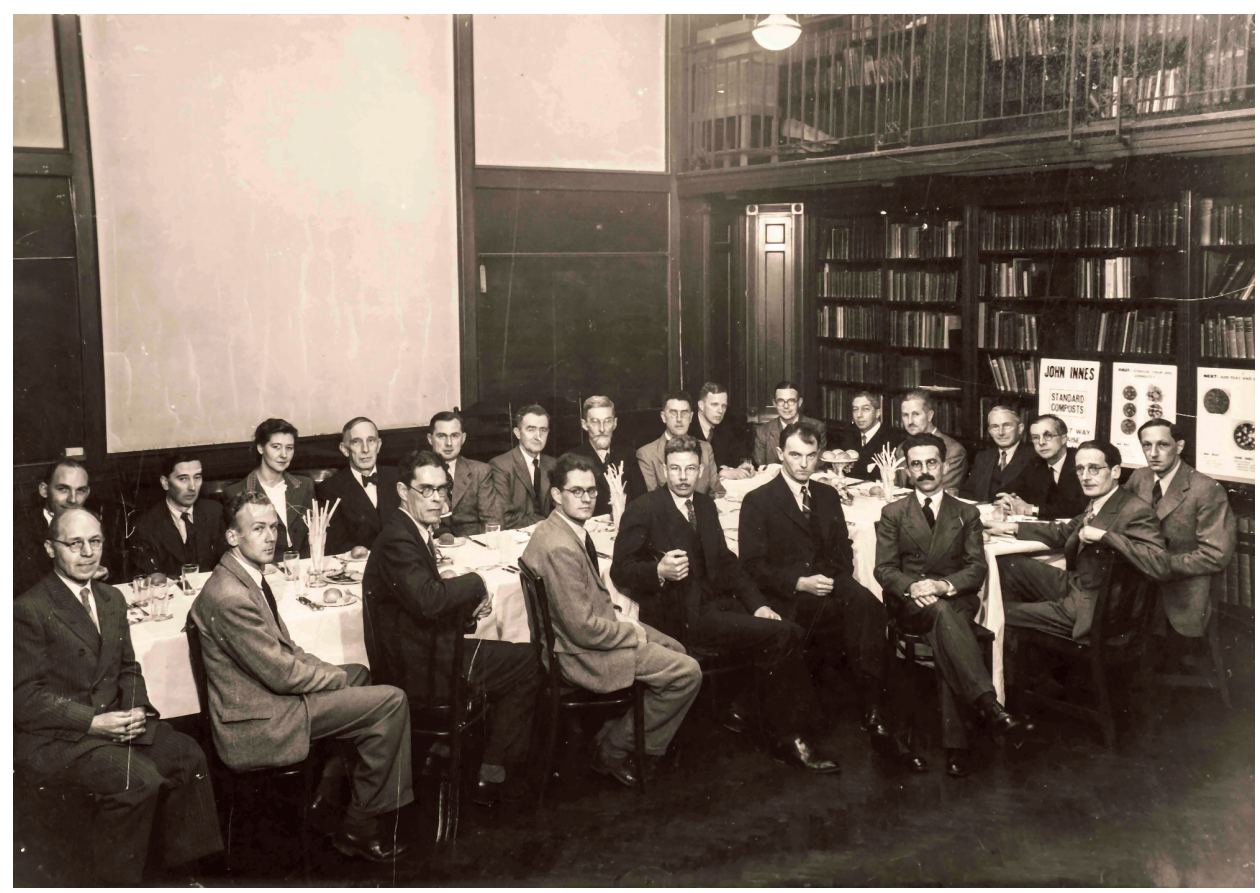

2. kép. A Genetics Society 1945-ös ülése a John Innes Intézet könyvtárában, Londonban. A hátsó sorban, balról a második Peo C. Koller (John Innes Archive, a John Innes Foundation jóvoltából)

\section{A MAGYAR KAPCSOLAT}

Koller 1931-ben kezdődő edinburgh-i tartózkodása egyszerre jelenti a fokozatos szakítást a katolikus egyházzal és Magyarországgal. Bár gyerekként lenyügözték a katolikus szertartások külsőségei, diákként már többször is szembesült egyházi elöljárói doktrinerségével. Amikor a Szentháromság mibenlétéről kérdezett, ráfogták, hogy nesztoriánus, még később pedig, amikor arra próbált választ kapni, hogy a szövettenyészetekben élő sejtekről milyen álláspontja van a bencés rendnek, még inkább falakba ütközött. A genetika determinisztikus logikája és a kutatólaborok világi közege pedig fokozatosan ráébresztette, hogy 
a szerzetesi élet nem neki való. Bár a bencés rend hivatalosan csak 1967-ben hagyta jóvá a kilépését, ekkorra a dán Anna Olsennel 1947-ben kötött házasságából származó három lánya (Christa, Karin és Pia) közül a legidősebb már nagykorú.

Magyarországra csak 1962-ben látogatott, de a kapcsolat sosem szakadt meg teljesen (részben a rokoni szálak miatt). Rockefeller-ösztöndíjas útjáról a Búvár magazin közöl cikkeket, 1945-ben pedig a korábbi mentor-barát, Szent-Györgyi Albert vezetésével megalakuló Magyar Természettudományi Akadémia tíz külföldi tagja közt, Hevesy György, Kármán Tódor és Neumann János mellett ott találjuk Kollert is.

A régi kapcsolatok mellett újakat hozott az 1958-as londoni nemzetközi rákkutató konferencia. Ekkor ismerkedett össze a területen dolgozó fiatal magyar kollégákkal, amit számos ösztöndíjas lehetöség követett, amely keretében magyar kutatók (az első köztük Lapis Károly) a Fulham Road-i intézetbe látogathattak. Ezeknek a kapcsolatoknak köszönhető az 1962-es hazalátogatás és előadás, amit utána rendszeres hazautazások követtek.

\section{AZ EUGENIKA ÁRNYÉKÁBAN}

Hivatalos szakmai önéletrajza és a publikációi alapján nem sejthető, de egyéb írásai alapján jól látható, hogy Kollert diákkorától élete végéig érdekelte az eugenika és a szociobiológia, illetve azok politikai következményei. Bár önéletrajzi feljegyzéseiben kifejezett távolságtartással nyilatkozott Méhelÿ Lajosról, feltehető, hogy doktori tanulmányai alatt az idős antiszemita mentornak komoly hatása lehetett a fiatal bencés szerzetes diák gondolkodására. Jól példázza ezt Koller 1926-ban megvédett, beszédes, Faj és haj címü doktori értekezése, amelynek témája és nyelvezete hủen visszhangozza Méhelÿ korabeli áltudományos eugenicista nézeteit (Koller, 1926a): „Ha pedig [a zsidó vér] állandóbb és ellenállóbb a magyar vérrel szemben, akkor mivel a vér, illetve a benne levő faji fehérje végső elemzésben összes testi és szellemi tulajdonságainknak is meghatározója, a zsidó fajtával való nagyobb mértékủ keveredés az egész magyar fajta halálos veszedelme volna, mert teljesen kivetkőztetné őseredeti jellegéből."

Egy korabeli doktori disszertáció esetében kevésbé meglepő, hogy az a témavezető gondolatvilágát tükrözi, ugyanakkor Koller hasonló húrokat pengetett, amikor ugyanebben az évben a Méhelÿ által szerkesztett $A$ Cél címü lapba írt cikket Fajvédelem és katholicizmus címmel (Koller, 1926b): „A katholikus fajvédőnek tehát active is élni kell az odium abominationis eszközével, mert a zsidó faj romlottsága másokat is romboló világnézetre csábít, miértis kötelességünk a zsidóban levő bünös és veszedelmes ösztönöket üldözni s ezek terjedését megakadályozni." 
Utólag már lehetetlen rekonstruálni, hogy ezek mennyire tükrözték Koller személyes meggyőződését, vagy mennyire vezethette a témavezetőjének való megfelelni akarás. Ugyanakkor jól nyomon követhető, hogy amint Koller kikerült Méhelÿ tanszékéről, és a kor vezető genetikusaival került kapcsolatba, az új élmények és információk radikálisan átírták a témához való viszonyulását. Alig pár évvel később, 1931-ben (vagyis két rövidebb ösztöndíjas időszak után) a Pannonhalmi Szemlében már így fogalmaz (Koller, 1931): „Amikor tehát szellemi tulajdonságok öröklődéséről beszélünk, akkor három tényezővel kell számolnunk, az örökléssel, a fizikai és szociális környezet hatásával. [...] Az igaz, hogy az öröklés a fejlődésnek határt szab. Ez a határ azonban nem olyan szük, mint hisszük és ezen belül az egyénnek birtokában lesz mindig a szabadság és a felelősségérzet tudata, melynek segítségével meg fogja találni életcélját és kiépítheti harmonikus életét."

Azaz miközben a kor számos kutatója egyre inkább elveszett az eugenika primitíven leegyszerüsítő és hibás, ugyanakkor könnyen emészthető logikájának büvöletében, Koller saját szakmai fejlődésének eredményeképpen ellenkező utat járt be. A folyamat bezárását jelenti az 1939-es kongresszus záró manifesztója (Crew et al., 1939), és az ezekben foglaltakhoz Koller egészen haláláig tartotta magát. Ez nemcsak a Magyar Televízióval készült riportból derül ki, hanem a pályájának lezárásaként írt Kromoszómák és gének címü munkájából (Koller, 1971b). A zárófejezet gondolatai napjainkban az emberi genomszerkesztés kapcsán megfogalmazott aggodalmak fényében különösen aktuálisan hangzanak: ,[K]i volna hivatott arra, hogy megállapítsa, a faj válogatott tovább élése szempontjából ki a »megfelelö« típus és milyen alapon? Melyik lenne az ideális embertípus, amelynek létrehozására kellene törekednünk? [...] [M]ég nincs itt az ideje, hogy akaratunk irányításával a megfelelő géneket be, a nem megfelelőket pedig ki tudjuk kapcsolni. Még mindig beláthatatlan ismeretlen területről kell pontos tudomást szereznünk ahhoz, hogy »genetikai müvi beavatkozást« tudjunk végrehajtani és képesek legyünk az emberi öröklődést és fejlődést szabályozni."

\section{KÖSZÖNETNYILVÁNÍTÁS}

A szerző köszönetet szeretne mondani Karin Kollernek, aki nemcsak személyes emlékeit, de édesapja önéletrajzi feljegyzéseit és fényképeit is megosztotta, Lapis Károlynak és Tony Daviesnek, akik visszaemlékezéseikkel segítették Koller Pius Károly életútjának rekonstruálását, valamint a Bodleian Library, az ELTE Levéltára és a Pannonhalmi Apátsági Levéltár munkatársainak segítségét a birtokukban levő kéziratok kikeresésében. 


\section{IRODALOM}

Beale, G. (1993): The Discovery of Mustard Gas Mutagenesis by AUERBACH and ROBSON in 1941. Genetics, 134, 393-399. https://www.ncbi.nlm.nih.gov/pmc/articles/PMC1205483/pdf/ ge1342393.pdf

Crew, F. A. E. - Darlington, C. D. - Haldane, J. B. S. et al. (1939): Social Biology and Population Improvement. Nature, 144, 521-522. DOI: 10.1038/144521a0, https://www.nature.com/articles/144521a0.pdf

Darlington, C. D. - Haldane, J. B. S. - Koller P. C. (1934): The Possibility of Incomplete Sex Linkage in Mammals. Nature, 133, 417. DOI: 10.1038/133417b0, https://www.nature.com/articles/133417b0.pdf

Davies, A. J (1980): Peo Koller - Obituary. Nature, 283, 117. DOI: 10.1038/283117a0, https://www. nature.com/articles/283117a0.pdf

Gyurgyák J. (2012): A tudós zoológus - Méhelÿ Lajos. In: Gyurgyák J.: Magyar fajvédők. Budapest: Osiris Kiadó, 87-102.

Koller K. P. (1926a): Faj és haj. Doktorátusi értekezés. Budapest: Magyar Egyetemi Nyomda

Koller K. P. (1926b): Fajvédelem és katholicizmus. A Cél, 16, 5, 147-151.

Koller P. (1930): On Pigmentation Formation in the D-black Rabbit. Journal of Genetics, 22, $103-$ 107. https://link.springer.com/content/pdf/10.1007/BF02983370.pdf

Koller K. P. (1931): Szellemi tulajdonságok öröklődése. Pannonhalmi Szemle, IV, 2, 125-130.

Koller P. C. (1939): Genetics of Natural Populations III. - Gene Arrangements in Populations of Drosophila pseudoobscura from Contiguous Localities. Genetics, 24, 1, 22-33. https://www. genetics.org/content/genetics/24/1/22.full.pdf

Koller P. C. (1946): The Implication of Genetical Effects Induced by Ionising Radiation. In: The Human Race. Welcome Library/UCL: Special Collections - Haldane Papers, HALDANE/2/2/1/14

Koller P. C. (1963): The Nucleus of the Cancer Cell. A Historical Review. Experimental Cell Research Supplement, 9, 3-14. DOI: 10.1016/0014-4827(63)90241-6

Koller P. C. (1971a): Interviews with Former Staff of the Institute of Animal Genetics 1969-1971 by Margaret Deacon. The University of Edinburgh Archives, EUA CA 16/1

Koller P. C. (1971b): Kromoszómák és gének. Budapest: Medicina Könyvkiadó

Koller Károly angliai rákkutató. Portréfilm, rendező Kígyós Sándor, Magyar Televízió, 1980 